\title{
Recurrent subcutaneous human Dirofilariasis due to Dirofilaria repens after surgical removal of the worm and anthelmintic treatment
}

\author{
M Lupșe ${ }^{1 *}$, Mircean $^{2}$, A Cavasi $^{1}$, AD Mihalca ${ }^{2}$ \\ From The 1st Conference on Neglected Vectors and Vector-Borne Diseases (EurNegVec): with Management \\ Committee and Working Group Meetings of the COST Action TD1303 \\ Cluj-Napoca, Romania. 8-11 April 2014
}

The genus Dirofilaria includes various species that are natural parasites of dogs, cats, foxes, and wild mammals, transmitted by mosquito vectors. Dirofilaria repens is commonly encountered in the subcutaneous tissue of dogs, foxes, and cats. Due to recent increase of human Dirofilaria repens it is considered an emerging zoonosis. In Romania, there are only few reports regarding the infection with $D$. repens in dogs and in humans. Patients usually present single migratory submucosal or subcutaneous nodule which may or may not be tender. Surgical excision of lesions and affected areas is the treatment of choice for dirofilariasis. Anthelmintics are not usually recommended.

We describe the case of a 65 years old, retired woman, without history of traveling in the past years, living in the Oradea (north-west part of Romania), in an urban area, who presented a left breast subcutaneous nodule with fever and eosinophilia in August 2012. After surgical excision, histopathology and PCR assay (Isolate Genomic DNA Kit, Bioline, UK using 12S ADNr gene (250 bp) the diagnosis of $D$. repens infection was established. Patient received Albendazole $400 \mathrm{mg} /$ day for 7 days after surgery. The eosinophil count became normal and no symptoms were noticed till December 2012 when another nodular lesion developed in the left breast, accompanied by eosinophilia. After the surgical removal of the second nodule, another larval worm was identified as D. repens. The patient was treated with $150 \mu \mathrm{g} / \mathrm{kg}$ BW of ivermectin and no other nodules appeared. Eosinophiles level remained normal during one year follow-up. This is the first report of autochthonous $D$. repens infection in humans in the

\footnotetext{
* Correspondence: mihaela.lupse@yahoo.com

'University of Medicine and Pharmacy "Iuliu Hațieganu" Cluj-Napoca, Romania

Full list of author information is available at the end of the article
}

northern part of the country and, to our knowledge, the first case of recurrent subcutaneous human dirofilariasis. The recurrence in this case is most probably the result of infection with multiple larvae, of which at least two developed into nodules at four month interval, rather than a repeated infection. We recommend the treatment with ivermectin after surgical excision to avoid recurrences in dirofilariasis.

\section{Authors' details}

'University of Medicine and Pharmacy "Iuliu Hațieganu" Cluj-Napoca, Romania. ${ }^{2}$ University of Agricultural Sciences and Veterinary Medicine, ClujNapoca, Romania.

Published: 1 April 2014

doi:10.1186/1756-3305-7-S1-P3

Cite this article as: Lupșe et al:: Recurrent subcutaneous human Dirofilariasis due to Dirofilaria repens after surgical removal of the worm and anthelmintic treatment. Parasites \& Vectors 2014 7(Suppl 1):P3.

Submit your next manuscript to BioMed Central and take full advantage of:

- Convenient online submission

- Thorough peer review

- No space constraints or color figure charges

- Immediate publication on acceptance

- Inclusion in PubMed, CAS, Scopus and Google Scholar

- Research which is freely available for redistribution 